\title{
Age-Related Changes in the Urinary Bladder of the Female Albino Rats
}

\author{
Cambios Relativos a la Edad en la Vejiga Urinaria de la Rata Albina Hembra
}

\author{
Mohamed Akram Al-Motabagani
}

AL-MOTABAGANI, M. A. Age-Related changes in the urinary bladder of the female albino rats. Int. J. Morphol., 23(4):309-316, 2005.

SUMMARY: Disturbances of the urinary bladder functions are common in the elderly people particularly women. So, it was the aim of the present work to detect the age-associated changes in the urinary bladder that might play a role in the bladder dysfunctions. Twenty albino rats were used in the present work. They were divided into two equal groups, each consisted of ten rats. The first group included the adult rats (aged 3 months) and served as control group, while the second group was the senile rats (aged 24 months). Specimens of the urinary bladder were taken, processed and examined using the light microscope (LM) and the scanning electron microscope (SEM).

Light microscopic examination of the urinary bladder of the aged rats showed marked mucosal damage, ranging from degeneration of the epithelial cells to complete denudation of the mucosa with exposed lamina propria. Cellular infiltration and increased dilated and congested blood vessels of the lamina propria were also encountered. The smooth muscle cells of the muscularis showed variable degrees of degeneration with wide separation of the muscle bundles. Massive increase in collagen fibres deposition was detected in the lamina propria, muscle layer and adventitia. SEM examination revealed loss of the polygonal cell pattern appearance of the superficial epithelial cells and an increase in the collagen fibres in all the portions of the mucosa, It was concluded that the observed age-related changes might be contributing factors in the urinary bladder disturbances in elderly population.

KEY WORDS: Urothelium; Urinary mucosa; Urinary muscularis; Bladder dysfunction.

\section{INTRODUCTION}

The urinary bladder is a highly distensible organ with an epithelium very compliant to tangential stress and a rich supply of nerves and vessels in the mucosa (Inoue \& Gabella, 1992). The normal function of the urinary bladder is storage and expulsion of urine. Micturation reflex manifests principally through activation of a cholinergic pathway on the bladder, but a purinergic system has also been described (Burnstock, 1997).

It is well known that disturbances of the urinary bladder functions are common in elderly people, particularly women, who often complain or urgency, frequency, nocturia and incontinence, usually as a complication of difficult labour (Resnick et al., 1989 and Horst \& Junemann, 2004). To assess the aging changes in the urinary bladder in humans, invasive procedures, such as catheterization, cystoscopy or biopsies are required, which may carry a risk for the patient. Moreover, it is difficult to precisely discriminate between dysfunctions belonging to pathology from those related to aging (Castleden et al., 1981).

Therefore, the present work was undertaken to study the age-related changes in the urinary bladder of female albino rats and to correlate them with urinary bladder dysfunction.

\section{MATERIAL AND METHOD}

Twenty Sprague Dawley female albino rats were used in this study. They were obtained from the animal house, College of Medicine, King Faisal University. The animals were divided into two groups, ten animals each. The first group included the adult rats (aged 3 months) and was 
considered as a control, while the second group constituted the senile rats (aged 24 months). The animals were sacrificed by decapitation. The anterior abdominal wall was opened and the urinary bladder was excised.

Light microscopic study. Immediately following excision, the urinary bladder was fixed in $10 \%$ formal saline solution. Specimens from the anterior wall of the bladder were processed for paraffin blocks and sectioned at a thickness of $7 \mu \mathrm{m}$. These sections were stained by routine hematoxylin and eosin and Masson's trichrome stain (Drury \& Wallington, 1983).

Scanning electron microscopic study. Strips of 3 - $5 \mathrm{~mm}$ from the anterior wall of the urinary bladder were immediately fixed in 2\% paraformaldehyde and $2.5 \%$ glutaraldehyde in $0.1 \mathrm{M}$ phosphate buffer for $24 \mathrm{~h}$; fixation and washing were carried out at $4^{\circ} \mathrm{C}$. The tissues were then dehydrated through ascending grades of ethanol and substituted with isomylacetate. The pieces of the urinary bladder were dried at critical point using liquid carbon dioxide $\left(\mathrm{CO}_{2}\right)$. The tissue specimens were mounted on stubs with aluminum conducting tape and sputter coated with 20 $\mathrm{nm}$ layer of gold in JFC ion. The specimens were examined and photographed with XL 30 scanning electron microscope (Philips) operated at $30 \mathrm{KV}$ (Robinson et al., 1987).

\section{RESULTS}

Group I (Adult female rats; control). The wall of the urinary bladder was made up of three layers namely, mucosa, muscularis (musculosa) and adventitia. The mucosa was thrown into numerous folds and consisted of a lining urinary epithelium, the urothelium, and a fibroelastic lamina propria. The lining epithelium was of the transitional type consisting of basal, intermediate and superficial cells. The basal cells

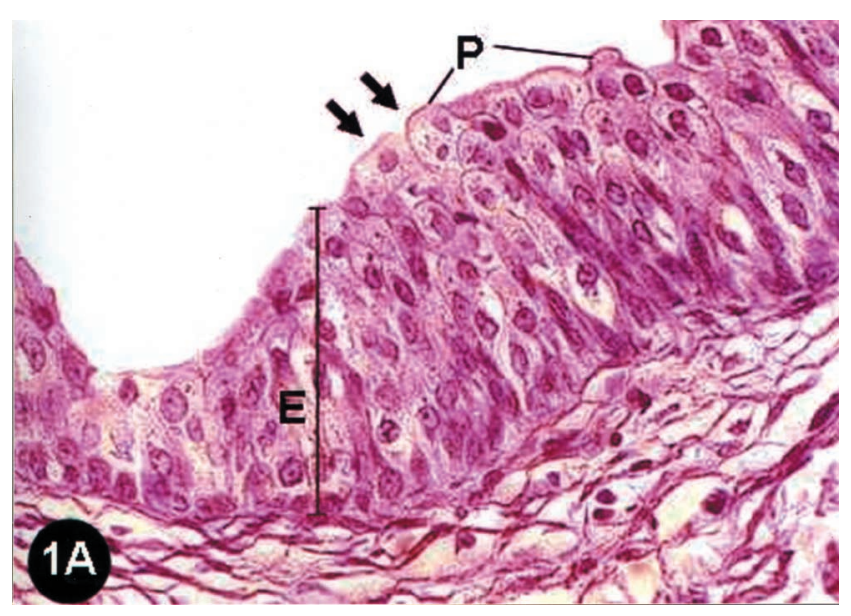

were mainly cuboidal in form with central nuclei. The intermediate cells were spindle-shaped and arranged with their long axes perpendicular to the basal lamina. The superficial cells were large and dome-shaped with abundant eosinophilic cytoplasm; some cells were binucleated. The luminal plasma membrane of the superficial cells showed a mosaic of thickened plaques regions interspersed by normal plasma membrane, the interplaque regions. The luminal border also showed deep invaginations giving the surface a characteristic scalloped appearance (Fig. 1A). The lamina propria consisted mainly of collagenous connective tissue containing small blood vessels. The connective tissue of the superficial part of the lamina propria was dense and irregular in type while in the deeper part it was relatively loose (Fig. 1B). The muscularis appeared to be formed of three interlaced layers; inner and outer thin longitudinal layers and a middle thick layer. As a result of intermingling of muscle fibers in these layers, the muscularis could not be clearly separated into three well-defined strata. The muscle fibers were arranged into groups separated by loose connective tissue septa (Fig. 1C).

Examination of the luminal surface of the urinary bladder with the scanning electron microscope revealed that the superficial urothelial cells were polygonal in outline with well-defined cell boundaries (Fig. 1D). The lamina propria appeared to be formed of superficial, middle and deep portions according to the arrangement of the collagen

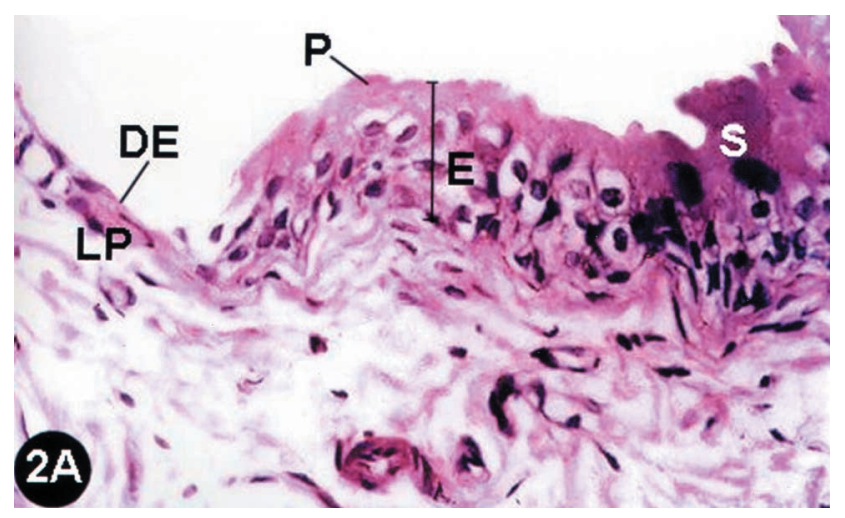

Figs. 1A and 2A. Photomicrographs of sections of the urinary bladder of adult (1A) and senile (2A) female rats showing the bladder mucosa. In the adult the mucosa was lined by a multilayered transitional epithelium, the urothelium (E). The luminal plasma membrane of the superficial cells showed a mosaic of thickened plaques $(\mathrm{P})$ regions interspersed by normal cell membrane, the interplaque regions. The luminal border also contained deep invaginations giving the surface typical scalloped appearance (arrows). In the senile rats the mucosa showed variable degrees of degeneration in the urothelium (E) with thickened apical plaques (P). Areas of denuded urothelium (DE) with exposed lamina propria (LP) were also present. Some of the superficial cells (S) showed hyperchromatic nuclei and deeply eosinophilic cytoplasm. H\&E stain, X540. 

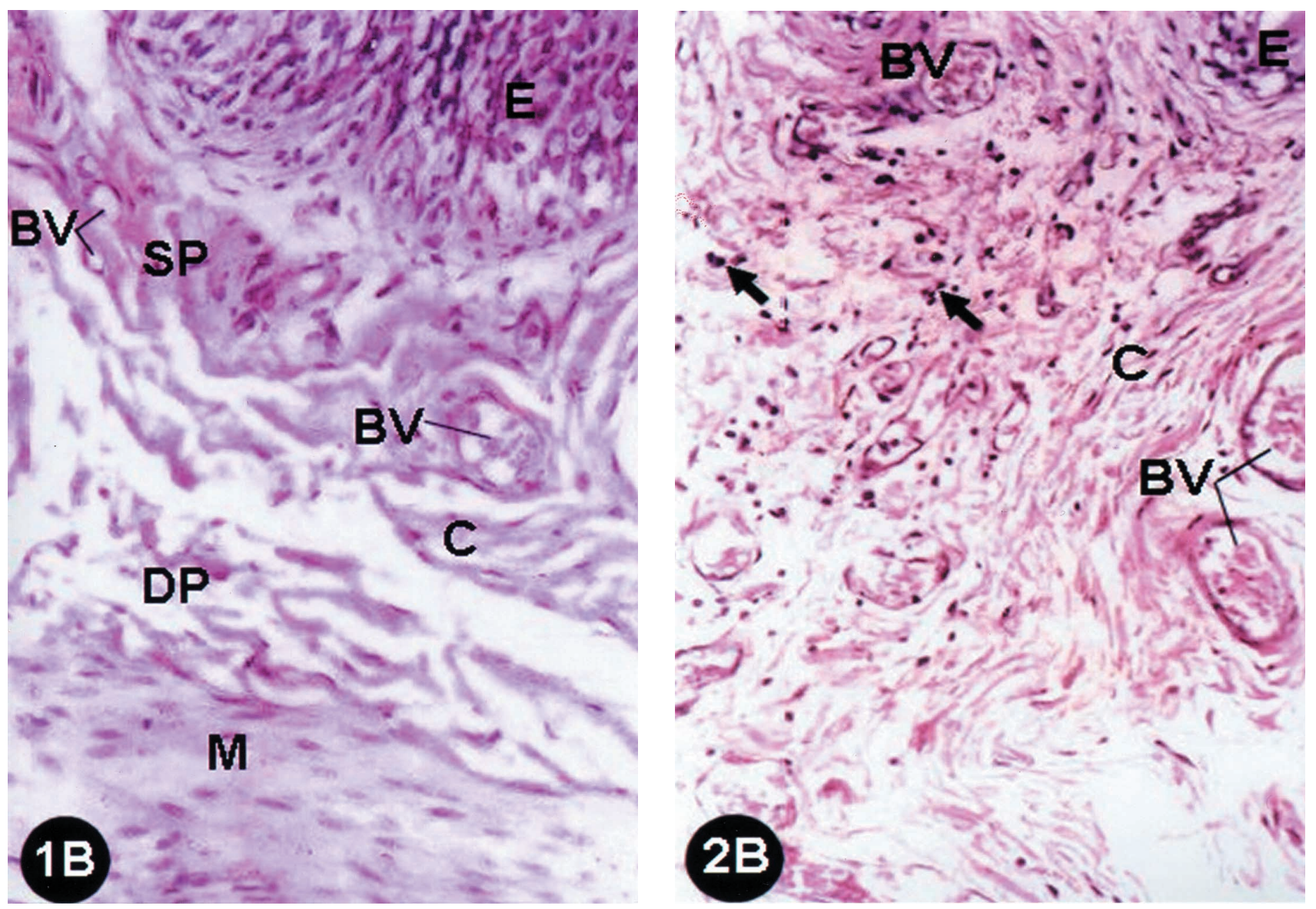

Figs. 1B and 2B. Photomicrographs of sections of the urinary bladder of adult (1B) and senile (2B) female rats showing the lamina propria of the mucosa. In the rats, the connective tissue in the superficial part (SP) of the lamina propria was of the dense irregular type due to heavy deposition of collagenous fibers (C). By contrast, the connective tissue in the deeper part (DP) was of the loose type. Numerous small blood vessels (BV) were present throughout the lamina propria especially in the superficial part. In the senile rats, the lamina propria was relatively thick as a result of massive increase in collagen fibers (C). Cellular infiltration (arrows) and many dilated and congested blood vessels (BV) were also present. In both photomicrographs the lining epithelium (E) is indicated, and in Figure 1B the superficial portion of the muscularis (M) is also indicated. H\&E stain, X540.

fibers. In the superficial and deep portions the collagen fibers were running in various directions forming networks; the network appeared denser in the superficial part. In the mid-portion the collagen fibers appeared to form flat tapelike bundles running parallel to the surface thus facilitating the division of the lamina propria into superficial and deep portions (Fig. 1E). On few occasions, muscle fascicles ensheathed by collagen fibers were also observed in the midportion of the lamina propria forming incomplete and rudimentary muscularis mucosae (Fig.1F).

Group II (Senile female rats). Examination of specimens of the urinary bladder of the senile rats revealed marked mucosal damage. The epithelial cells showed variable degrees of degeneration. Most of the cells showed vacuolated cytoplasm with peripherally placed nuclei. Few cells especially in the superficial layer appeared with hyperchromatic large nuclei and deeply acidophilic cytoplasm. The luminal surface of the epithelium showed enormous increase in the thickness of the apical plaques.

Areas of complete denudation of the mucosa with exposed lamina propria were also encountered (Fig. 2A). The lamina propria showed an increase of dilated and congested blood vessels with cellular infiltration especially near them (Fig. 2B). A massive increase in the collagen fibres in the lamina propria compared to control was also detected (Fig. 2B). The muscularis showed wide separation of the muscle bundles, some of them appeared lightly stained with absent nuclei. The arrangement of the muscle layer was markedly distorted in some areas giving a trabeculated appearance (Fig. 2C). 

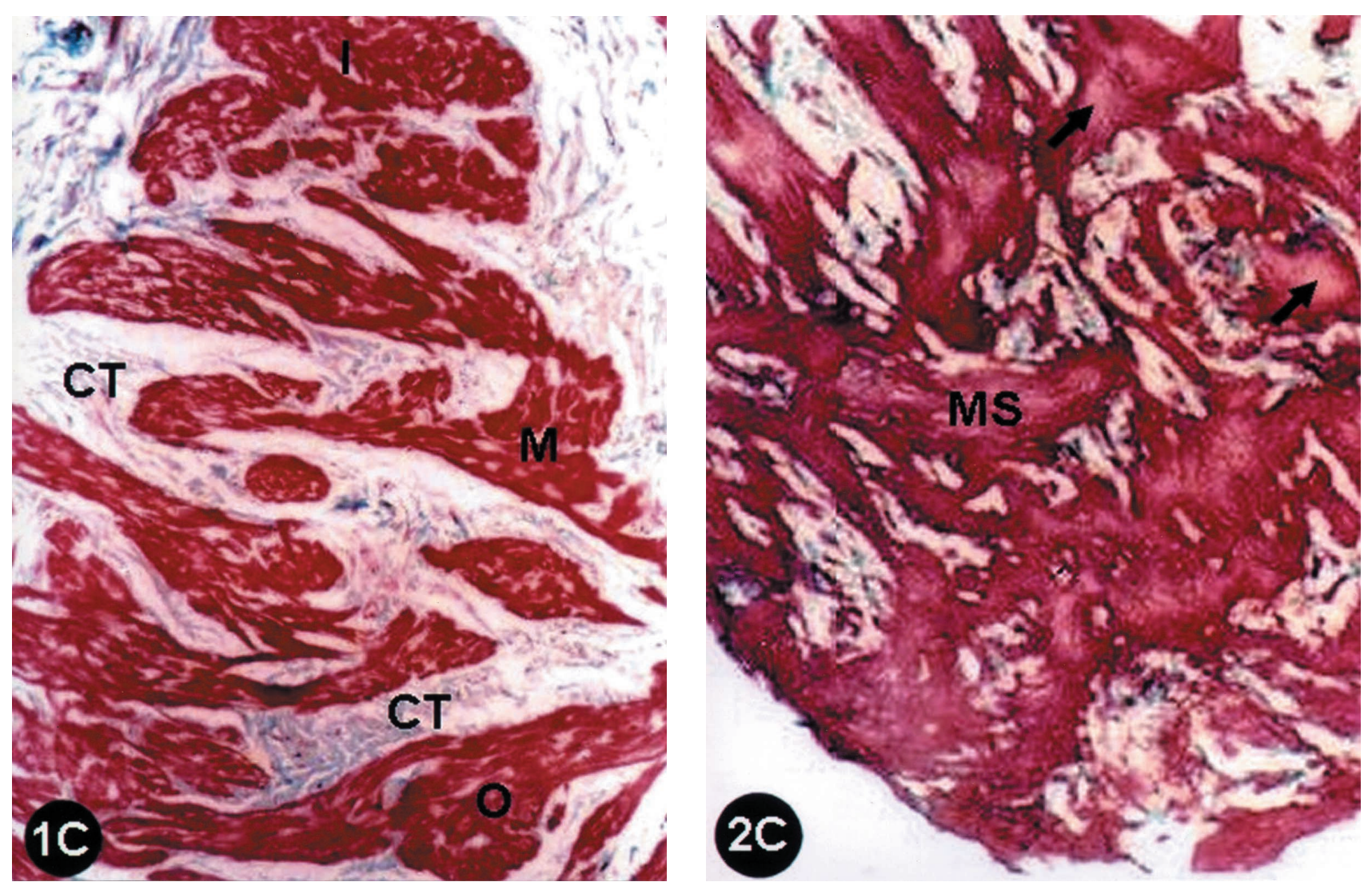

Figs. 1C and 2C. Photomicrographs of the muscularis (the detrusor muscle) of the urinary bladder of adult (1C) and senile (2C) female rats. In the adult the muscularis was moderately thick consisting of three interlaced layers of smooth muscle. The myofibers were arranged into groups separated by partitions of connective tissue (CT). The myofibers appeared to be running mainly in a longitudinal direction in the inner (I) and outer $(\mathrm{O})$ layers, and are arranged circularly in the middle layer (M). The latter appeared to be the most prominent. In the senile rate the muscularis (MS) was distorted in arrangement and showed a trabeculated appearance. Some of the myofibers were lightly stained with absent nuclei (arrows). Masson's trichrome stain, X270.
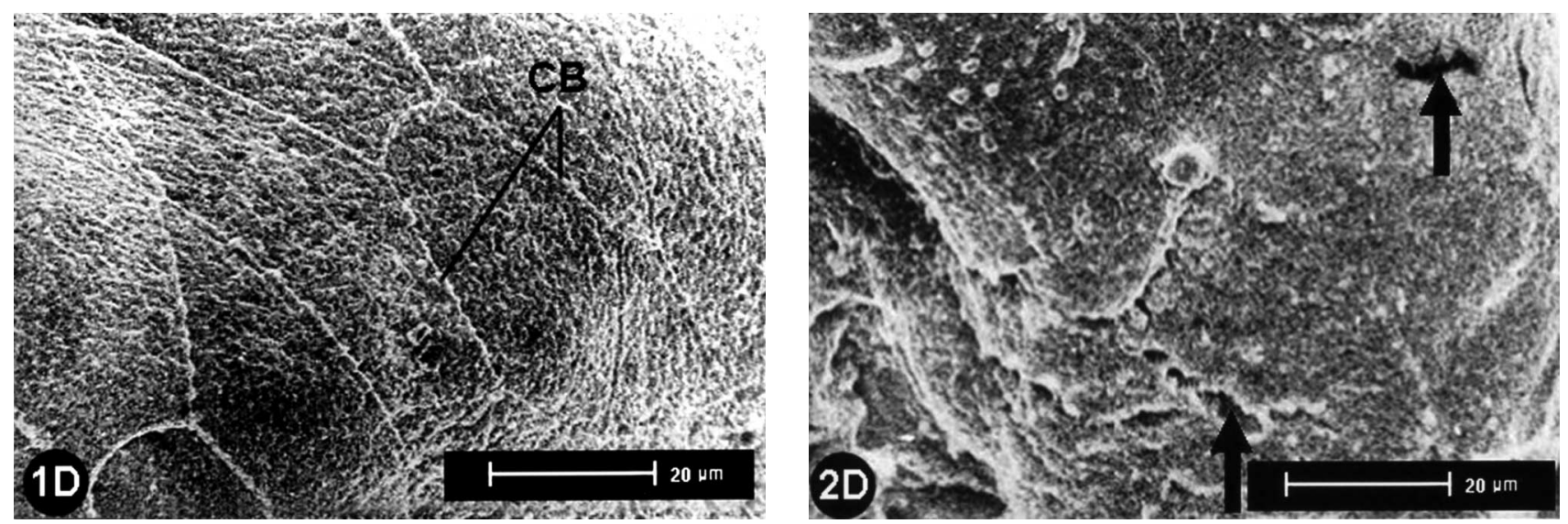

Figs. 1D and 2D. Scanning electron micrographs of the urinary bladder of adult (1D) and senile (2D) female rats showing the luminal surface. In the adult rats the surface of the superficial urothelial cells was polygonal with well defined cell boundaries (CB). In the senile rats the polygonal cell appearance was lost and focal areas of denuded urothelium were present (arrows).

Examination of the luminal surface with the scanning electron microscope showed loss of the polygonal cell pattern of the superficial cells with indistinct cell boundaries (Fig. 2D). The Urothelium also showed focal denuded areas (Fig. 2D). Collagen fibres were found to be markedly increased in density with an irregular arrangement in all the portions of the lamina propria (Figs. 2E). 

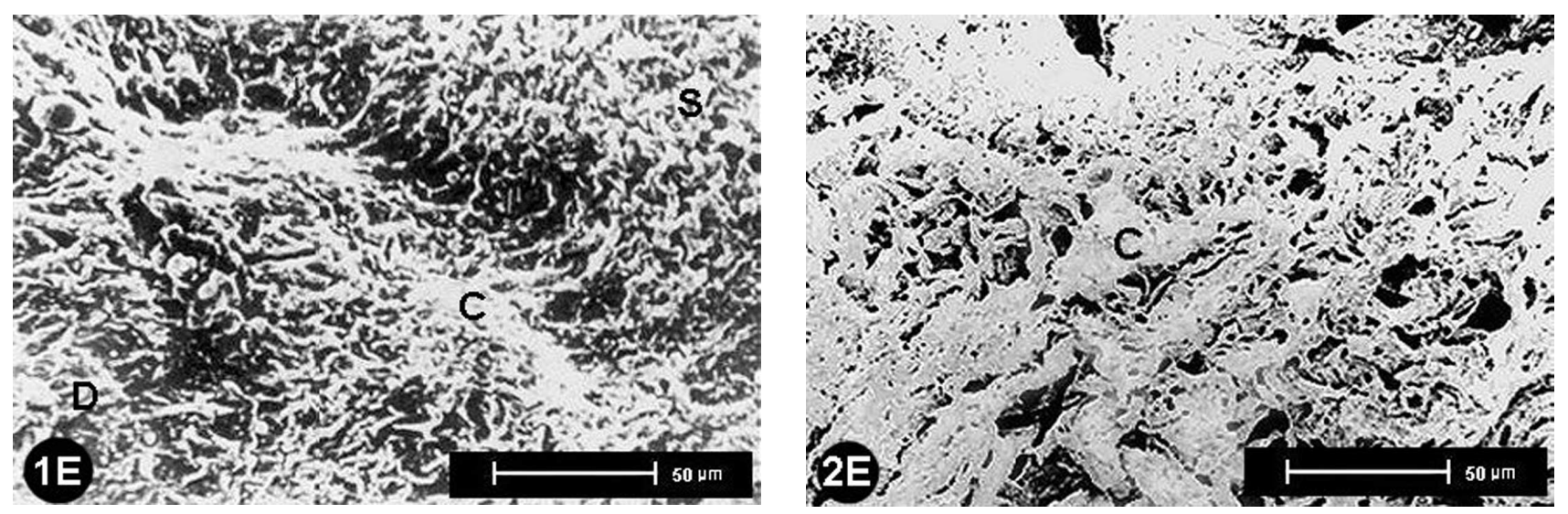

Figs. 1E and 2E. Scanning electron micrographs of sections of the urinary bladder of adult (1E) and senile (2E) female rats showing the arrangement of collagen fibers in the lamina propria. In the adult rats the collagen fibers form a dense network in the superficial part (S) of the lamina propria and relatively a looser network in the deep part (D). It is interesting to note that the collagen fibers (C) appeared to form flat tape-like bundles in the mid-portion of the lamina propria. In the senile rate, there was a massive increase in the density of collagen fibers (C) in all parts of the lamina propria.

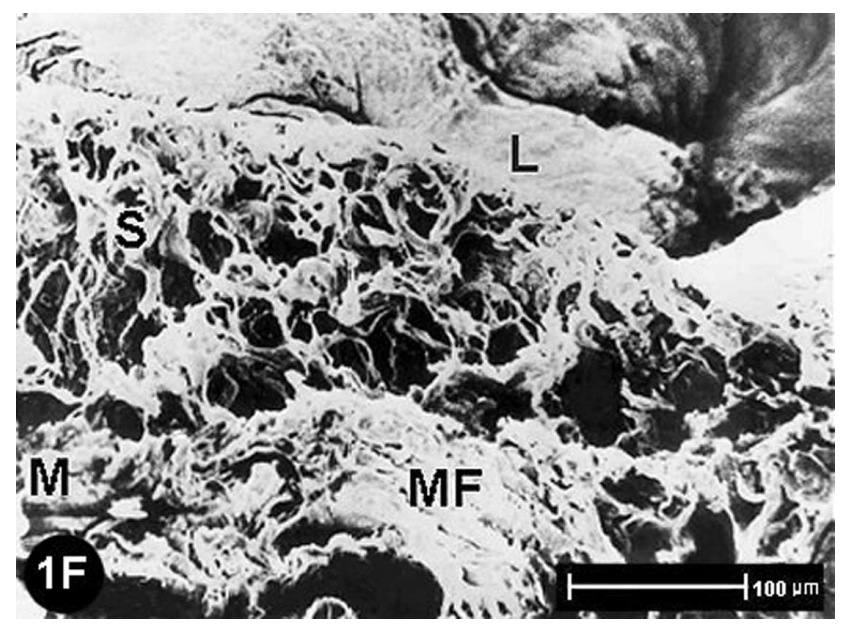

DISCUSSION

Voiding dysfunction in elderly is a common problem. The aging effects on the bladder function include decreased bladder capacity, increased detrusor instability with uninhibited contractions, decreased urinary flow rate and decreased urethral resistance (Elbadawi et al., 1993 and Wagg \& Malone-Lee, 1998).

In the present study, the superficial epithelial cells of the urothelium of the adult bladder showed thickened luminal plasma membrane in the form of apical plaques. In agreement with the present finding, Jezernick \& Pipan (1993) reported that the urothelium serves as an effective blood-urine permeability barrier. This function is maintained by the tight junctional complexes that seal the
Fig. 1F. Scanning electron micrographs of a cut surface view of the mucosa of the urinary bladder of adult female rat showing the luminal surface (L) and the superficial(S) and middle (M) portions of the lamina propria. Note the presence of collagen-sheathed muscle fascicle (MF) in the middle portion.

spaces between the adjacent superficial cells and by the asymmetrical plasma membranes of these cells, which are covered by glycosaminoglycans that form rigid plaques. It was postulated that the apical plaques are synthesized in the terminally differentiated superficial cells (Hodges, 1997). In the present study the aged urinary bladder showed an increase in the thickness of the apical plaques in some areas and complete desquamation of the urothelial cells in other area. Jezernick et al. (1995) reported that the desquamation of the epithelial cells is a result of alteration in cell junctions. Jezernick et al. (2000) added that as a consequence of cellular detachment, due to desquamation or apoptosis, the urothelium loses its function as a barrier in distinct areas; the remaining basal cells in the intact areas proliferate and differentiate. The terminal differentiating cells will produce more uroplakins or cytokeratins resulting in increased thickness of the apical plaques. The detected mucosal damage in the aging bladder in the present work might be explained by decreased blood flow to the bladder as consequence of atherosclerosis which is a common disorder in old age (Saito et al., 1999). Ischemia induces urothelial damage due to disruption of cell junctions and increased susceptibility to infection (Korosec \& Jezernick, 2000). It has been indicated that the disruption of the urothelial permeability barrier might irritate the underlying layers of the bladder wall promoting inflammation as well as increased urinary frequency, urgency and bladder pain 
(Zeidel, 1997). In accord, the examined lamina propria of the aged bladder in the present work showed cellular infiltration with numerous dilated and congested blood vessels that might be a sign of inflammation. Parwani et al. (2004) reported that the denuding urothelium might be a manifestation of denuding cystitis that has been recognized in association with flat carcinoma in situ with exfoliation of the neoplastic epithelial cells.

In the present investigation, the lamina propria was composed of a superficial dense and a deep loose connective tissue layers. The most superficial part of lamina propria slightly indented the basal urothelial surface and housed blood capillaries that were very close to the overlying urothelium. Inoue \& Gabella and Gartner \& Hiatt (2001) have previously recorded similar findings and mentioned that the dense network of blood capillaries that circulate at the closest possible distance from the epithelium might play a role in the transport of solutes and in the inflammatory response to any irritation to the bladder mucosa.

In the present study, scanning electron microscopic examination revealed the arrangement of collagen fibres in the mucosa in three portions namely superficial, middle and deep. In the superficial part the collagen fibres were arranged individually in various directions. By contrast, in the middle portion the collagen fibres were arranged in flat tape-like bundles that appeared to be running parallel to the surface. In the deep portion the collagen fibers were condensed forming a network. These observations are consistent with those of Murakumo et al. (1995) who examined human urinary bladder by scanning electron microscopy, and indicated that collagen in the superficial portion provides support and protection for the transitional epithelium against over-distention and in the middle and deep portions it supports and protects blood vessels and nerves against external forces.

In the present work, smooth muscle fascicles were detected in the middle portion of the mucosa surrounded by collagen fibres. Murakumo et al. also detected the same finding and mentioned that the smooth muscle fascicles form discontinuous lamina muscularis mucosae. Weaver \& Abdul-Karim (1990), also recorded that the muscularis mucosae was present in $35 \%$ of the examined human cases, it was complete in $1 \%$, partial in $6 \%$ and minimal in $28 \%$ of cases. The occurrence of partial or complete muscularis mucosae was ten times more likely in women than in men and this finding was not associated with any known disease nor was it related to patient age. Their study was essential to differentiate between the normal findings and the muscle invasive bladder tumors.
In the current study, the collagen content in both the lamina propria and muscularis was increased with wide separation of the muscle bundles in the aged bladder. Elbadawi et al. detected the same finding in the human aging bladder and mentioned that although collagen is ordinary produced by fibroblasts, the detected fibroblasts were not so numerous to produce such excess of collagen. They found that there were fibroblast-like muscle cells within the muscle fascicles and concluded that the smooth muscle cells can actively produce collagen and this increase in collagen content may be an expression of a dedifferentiation of muscle cells associated with aging which modulates their transformation from a mature contractile to an immature synthetic matrix-secreting phenotype. On the other hand, Lluel et al. (2000) detected a significant decrease in collagen density in the urinary bladder of the aging female rat.

In the present work, the aging detrusor also showed signs of degeneration in the form of the light staining of the muscle bundles with the absence of nuclei of some of smooth muscle cells. In addition, there was an irregular arrangement of the three muscle layers of the muscularis in some areas. Holm et al. (1995) mentioned that fibrosis of the detrusor as a part of aging may explain the high incidence of bladder trabeculation found among female autopsies. A wide range of anatomic and physiologic changes have been described in the aging detrusor, including alterations in cell junctions, changes in sensitivity of sensory afferents, decreased innervations, increased collagen content and increased space between muscle cells (Warburton \& Santer, 1994). It is known that for the proper bladder emptying, intrinsic nerves trigger the detrusor contractility and the interstitium ensures that the contraction involves that the entire detrusor in coordination with the opening of the urethral conduit (Elbadawi et al.). There are two distinct components to detrusor contraction. The major component is cholinergic neurotransmission mediated by acetylcholine and the second is purinergic neurotransmission mediated by adenosine triphosphate (Yoshida et al., 2001). Age-related changes in the cholinergic and purinergic components of detrusor contraction may be a contributing factor in the development of detrusor over-activity (Yoshida et al., 2004). Overactive bladder is a common disease observed in the elderly population and is the most common cause of the incontinence (Haferkamp \& Elbadawi, 2004). It is known that the postganglionic parasympathetic neurons are the major source of acetylcholine in the bladder (Anderson et al., 2001). Results from previous studies detected another source of acetylcholine in the bladder (Wessler et al., 1998). It has been reported that the source of this non-neuronal acetylcholine is likely to be urothelial cells and the release is evoked by stretched and increases with age (Yoshida et 
al., 2004). The latter authors also indicated that the nonneuronal acetylcholine may play a role in the regulation of the bladder tone in the storage phase of the micturation reflex, particularly in the elderly and so, the antimuscarinic agents are effective fore the treatment of detrusor over- activity. The observed mucosal damage, increased collagen deposition as well as degeneration of the smooth muscle fibers in the aged rats of the present study might be contributing factors in the disturbances of the urinary bladder function recorded in elderly people.

AL-MOTABAGANI, M. A. Cambios relativos a la edad en la vegija urinaria de la rata albina hembra. Int. J. Morphol., 23(4):309-316, 2005.

RESUMEN: Disturbios de las funciones de la vejiga urinaria son comunes en las personas ancianas particularmente en mujeres. Por tanto, el objetivo de este trabajo fue detectar los cambios asociados con la edad, en la vejiga urinaria, los que pueden jugar un rol en las disfunciones vesicales. Fueron utilizadas 20 ratas albinas, las cuales fueron divididas en dos grupos, de 10 ratas cada uno. El primer grupo incluyó las ratas adultas (3 meses de edad) y sirvió como grupo control, en cuanto al segundo grupo, fue el de las ratas seniles ( 24 meses de edad). Fueron tomadas muestras de vejiga urinaria, procesadas y examinadas usando microscopio de luz (ML) y microscopio electrónico de barrido (MEB).

Al examen con ML la vejiga urinaria de las ratas seniles mostraron un marcado daño de la mucosa, desde degeneración de las células epiteliales hasta completa denudación de la mucosa con exposición de la lámina propria. Fue también encontrada infiltración celular y vasos sanguíneos de la lámina propria aumentados dilatados y congestionados. Las células musculares lisas de la capa muscular mostraron grados variables de degeneración con vasta separación de los fascículos musculares. Incremento masivo en la disposición de las fibras colágenas fue detectada en la lámina propria, capa muscular y adventicia. El examen al MEB reveló pérdida de células poligonales, aparición de patrón de células epiteliales superficiales y un incremento en las fibras colágenas en todas las porciones de la mucosa. Se puede concluir que los cambios observados relativos a la edad podrían ser uno de los factores contribuyentes en los disturbios de la vejiga urinaria en la población senil.

PALABRAS CLAVE: Epitelio urinario; Mucosa urinaria; Capa muscular de la vejiga; Disfunción vesical.

\section{REFERENCES}

Anderson, K. E.; Chapple, C. \& Wein, A. The basis for drug treatment of the overactive bladder. Worl. J. urol., 19: 294$8,2001$.

Burnstock, G. The past, present and future of purine nucleotides as signaling molecules. Neuropharmacology, 36:1127-39, 1997.

Castleden, C. M.; Duffin, H. \& Asherm, M. Clinical and urodynamic studies in 100 elderly incontinent patients. Brit. Med. J., 282:1103-5, 1981.

Drury, A. \& Wallington, E. Carleton's histological techniques 5th ed. Oxford University Press. Oxford, New York, 1983.

Elbadawi, A.; Yalla, S.V. \& Resnick, N. M.Structural basis of geriatric voiding dysfunction. (I) Methods of a prospective ultrastructural/urodynamic study and an overview of the findings. (II) Aging detrusor: Normal versus impaired contractility. J. Urol., 150:1650-67, 1993.

Gartner, L. P. \& Hiatt, J. L. Urinary system In: color textbook of histology. 2. ed. WB Saunders Company. London. 2001. pp458-9.
Haferkamp, A. \& Elbadawi, A. Ultrastructural changes in the aging bladder. Urologe, 43(5):527-4, 2004.

Hodges, G. M. A morphofunctional profile of stromalinduced effects on the epithelial phenotype in the tunica mucosa of the urinary bladder In: Motta PM (ed). Recent advances in microscopy of cells, tissue and organs. Rome, 1997. pp 495-500.

Holm, N. R.; Horn, T. \& Hald, T. Detrusor in aging and obstruction. Scand. J. Urol. Nephrol., 29: 45-9, 1995.

Horst, C. \& Junemann, K. The aging bladder. Anatomy and physiology. Urologe, 43(5):521-6, 2004.

Inoue, T. \& Gabella, G. Interface between epithelium and lamina propia in the rat urinary bladder. Arch. Histol. Cytol.,55 Suppl:157-63, 1992.

Jezernik, K. \& Pipan, N. Blood-urine barrier formation in mouse urinary bladder development. Anat. Rec., 235: 533-8, 1993.

Jezernik, K.; Medalia, O. \& Aronson, M. A comparative 
study of the desquamation of urothelial cells during gestation and in adult mice following moderate stress or endotoxin treatment. Cell Biol. Int., 19: 887-93, 1995.

Jezernik, K.; Romih, R. \& Veranic, P. Urothelial cell detachment and differentiation in urinary bladder. Pflugers Arch. Eur. J. Physiol., 439 (Suppl.): R135R136, 2000.

Korosec, P. \& Jezernik, K. Early cellular ultrastructural response of the mouse urinary bladder urothelium to ischemia. Virchows Arch., 436:377-83, 2000.

Lluel, P.; Palea, S.; Barras, M.; Grandadam, F.; Heudes, D.; Bruneval, P.; Corman, B. \& Martin, D.J. Functional and morphological modifications of the urinary bladder in aging female rats. Am. J. Physiol. Regulatory Integrative Comp. Physiol., 278:R964-R972, 2000.

Murakumo, M.; Ushiki, T.; Abe, K.; Matsumura, K.; Shinno, Y. \& Koyanagi, T. Three-dimensional arrangement of collagen and elastic fibres in the human urinary bladder. A scanning electron microscopic study. J. Urol.,154: 251-6, 1995.

Parwani, A.V.; Levi, A.W.; Epstein, J. I. \& Ali, S. Z. Urinary bladder biopsy with denuded mucosa: Denuding cyctitis - cytopathologic correlates. Diagn. Cytopath., 30(5): 297-300, 2004.

Resnick, N. M.; Yalla, S.V. \& Laurino, E. The pathophysiology of urinary incontinence among institutionalized elderly persons. N. Engl. J. Med., 320: 1-7, 1989.

Robinson, D. G.; Uhlers, V.; Herken, R.; Hermann, B.; Mayer, F. \& Schurmann, F. W. Methods of preparation for electron microscope. Publ. Springer - Verlag, Berlin, New York, 1987. pp 23-66 and 148-64.

Saito, M.; Ohmura, M. \& Mondo, A. Effect of aging on blood flow to the bladder and bladder function. Urol. Int., 62 (2):93-8, 1999.

Wagg, A. \& Malone-Lee, J. The management of urinary incontinence in the elderly. Br. J. Urol., 82:11-17, 1998.

Warburton, A. L. \& Santer, R.M. Sympathetic and sensory innervation of the urinary tract in young adult and aged rats: a semo-quantitative histochemical and immunohistochemical study. Histochem. J., 26:127-33, 1994.
Weaver, M.G. \& Abdul-Karim, F.W. The prevalence and character of the muscularis mucosae of the human urinary bladder. Histopathology, 17: 563-6, 1990.

Wessler, I.; Kirkpatrick, C.J. \& Racke, K. Non-neuronal acetylcholine, a locally acting molecule, widely distributed in biological systems: expression and function in humans. Pharmacol. Ther., 77: 59-79, 1998.

Yoshida, M.; Homma, Y. \& Inadome, A. Age-related changes in cholinergic and purinergic neurotransmission in human isolated bladder smooth muscles. Eep. Gerontol. 36: 99-109, 2001.

Yoshida, M.; Miyamae, K.; Iwashita, H.; Otani, M. \& Inadome, A. Management of detrusor dysfunction in the elderly: changes in acetylcholine and adenosine triphosphate release during aging. J. Urol., 63 (Suppl. 3A):17-23, 2004.

Zeidel, M. L. Functional anatomy of the mammalian urinary bladder. In: Sips IG, McQueen CA, Gandolf AJ (eds). Comprehensive toxicology, Oxford, 1997.
Correspondence to: Dr. M. A. Al-MMotabagani Chairman and Head Department of Anatomy, College of Medicine, King Faisal University, P.O. Box 2114

Dammam 31451

SAUDI ARABIA

Tel: Office + 966.3.8577000 (ext. 2073 and 2364)
Residence +966.3 .8577902

Mobile + 966.502.477278

Email:drmafm@hotmail.com

Received : 28-06-2005

Accepted: 23-09-2005 